\title{
PEMETAAN KONTUR LINGKUNGAN PADA MOBILE ROBOT MENGGUNAKAN WIIMOTE
}

\author{
Randy Erfa Saputra \\ Fakultas Teknik Elektro, Universitas Telkom \\ resaputra@telkomuniversity.ac.id
}

\begin{abstract}
Abstrak
Navigasi merupakan kemampuan dasar yang harus dimiliki oleh mobile robot sebelum dapat melaksanakan tugasnya dan pemetaan merupakan hal yang utama dalam permasalahan navigasi. Robot memerlukan peta sebagai dasar pengetahuan dari lingkungannya serta sensor-sensor yang berfungsi untuk mengenali keadaan lingkungannya. Pada penelitian ini dirancang sebuah sistem untuk membuat kontur lingkungan dengan memanfaatkan Wiimote pada mobile robot. Output yang dihasilkan berupa plot tiga dimensi dari titik-titik $(x, y, z)$ yang diperoleh dari kontur permukaan yang dilewati robot, dengan mengimplementasikan perangkat lunak untuk komunikasi data antara laptop dengan Wiimote dan mobile robot, serta melakukan perhitungan untuk menentukan keadaan kontur lingkungan. Hasil yang diperoleh adalah sistem dapat membuat peta kontur lingkungan yang mendekati keadaan lingkungan yang sebenarnya dengan akurasi rata-rata sebesar $93 \%$.
\end{abstract}

Kata kunci: Wiimote, accelerometer, mobile robot, kontur

\section{Abstract}

Navigation is basic skills that must be owned by the mobile robot before perform its tasks and mapping is a main issue in navigation problem. Robot needs a map as a basic knowledge of the environment and sensors to recognize the condition of its environment. In this paper, we designed a system to create environment contour by using Wiimote on the mobile robot. Outputs were produced in the form of three-dimensional plot of the points $(x, y, z)$ that was obtained from surface contour passed by robot, by implementing software for data communication between laptop, Wiimote, and mobile robot, and performed calculation to determine the environment contour. The results show that system can create environment contour which nearly match the actual condition with average accuracy of $93 \%$.

Keywords: Wiimote, accelerometer, mobile robot, contour

\section{Pendahuluan}

Mobile robot merupakan salah satu jenis robot yang memiliki kemampuan bergerak bebas di lingkungannya dan tidak terpaku pada satu tempat tertentu saja. Kata robot sendiri berasal dari bahasa Czech "robota" yang berarti pekerja dan diperkenalkan ke publik pada tahun 1920 melalui pertunjukan karya Karel Čapek yang berjudul Rossum's Universal Robot [7]. Pertunjukan tersebut bercerita tentang mesin yang menyerupai manusia tapi mampu bekerja terus-menerus tanpa lelah. Sedangkan jika merujuk pada American Heritage Dictionary, robot adalah sebuah alat mekanik yang terkadang menyerupai manusia dan mampu melakukan berbagai tugas rumit berdasarkan perintah atau telah terprogram sebelumnya.

Navigasi merupakan kemampuan dasar yang harus dimiliki oleh mobile robot sebelum dapat bergerak melaksanakan tugas dan fungsinya. Permasalahan navigasi dapat dimisalkan dengan menjawab pertanyaan dasar seperti "di manakah saya?", "kemana tujuan saya?", dan "bagaimanakah caranya agar saya dapat mencapai tujuan tersebut?".
Jawaban atas ketiga pertanyaan tersebut sangat penting untuk kepentingan navigasi pada robot. Oleh karena itu, robot memerlukan peta sebagai dasar pengetahuan dari lingkungannya serta sensor-sensor yang berfungsi untuk mengenali keadaan lingkungannya tersebut, sehingga masalah pemetaan ini menjadi hal yang utama dalam permasalahan navigasi pada robot $[2,5]$.

Tujuan dari penelitian ini adalah untuk membuat peta dari lingkungan yang berkontur dengan memanfaatkan Wiimote pada mobile robot. Output yang akan dihasilkan berupa plot tiga dimensi dari titik-titik $(x, y, z)$ yang diperoleh dari kontur permukaan yang dilewati robot.

\section{Wiimote}

Wii remote, atau yang biasa disingkat dengan "Wiimote", merupakan pengendali utama untuk console Nintendo Wii. Salah satu fitur utama dari Wiimote ini adalah kemampuannya untuk mendeteksi pergerakan (motion sensing), yang memungkinkan penggunanya berinteraksi dan memanipulasi itemitem di layar melalui pengenalan gerak (gesture 
recognition) dan penunjukan yang akurat dengan menggunakan accelerometer dan teknologi sensor optik. Fitur lainnya adalah kemampuan Wiimote untuk menggabungkan perangkat ekstensi lainnya, seperti Nunchuk dan Classic Controller untuk menambah sensasi dan pengalaman bermain game. Namun, dalam penelitian ini cukup hanya menggunakan sebuah Wiimote tanpa perangkat ekstensi.

Wiimote memiliki kemampuan untuk mendeteksi percepatan dari ketiga sumbu X, Y, dan Z melalui penggunaan accelerometer ADXL330. Accelerometer ini memiliki jangkauan pengukuran sebesar $\pm 3 g$ (gravity) dengan tingkat sensitivitas sebesar 1\% [1]. Accelerometer ini memiliki enam derajat kebebasan dimana sumbu positif $X$ ke arah kiri, sumbu positif Y ke arah belakang, dan sumbu Z positif ke arah atas. Gambar 1 menunjukkan sistem koordinat tersebut beserta dengan arah positifnegatifnya.

Pada keadaan diam, Wiimote tidak memberikan data percepatannya melainkan data hasil pembacaan sensor pada keadaan gravitasi yang dialami oleh Wiimote. Misalnya, saat diletakkan di atas meja yang datar dengan keadaan Wiimote menghadap ke atas, maka data pembacaan sensor akan memberikan nilai $+1 \mathrm{~g}$ pada arah sumbu $Z$ dan nilai 0 pada sumbu $X$ dan Y. Hal ini disebabkan pada saat Wiimote diletakkan di atas meja, gaya gravitasi hanya bekerja pada arah sumbu Z. Fitur motion sensing inilah yang akan digunakan di dalam penelitian ini.

\section{Kinematika Mobile Robot}

Mobile robot merupakan salah satu jenis robot yang memiliki kemampuan bergerak bebas di lingkungannya dan tidak terpaku pada satu tempat tertentu saja. Dewasa ini mobile robot banyak digunakan baik untuk penelitian ataupun untuk membantu manusia mengerjakan tugas spesifik, misalnya sebagai penyedot debu atau pemotong rumput. Selain itu, mobile robot juga dapat ditemukan dalam industri, militer, dan keamanan lingkungan.

Kinematika adalah ilmu yang mempelajari tentang gerak dari suatu benda tanpa memperhitungkan penyebab gerak benda tersebut. Jika dikaitkan dengan mobile robot, ilmu ini mempelajari pergerakan robot terhadap sistem kerangka koordinat tanpa memperhatikan gaya yang menyebabkan pergerakan tersebut. Pada penelitian ini digunakan mobile robot jenis differential drive.

Gambar 2 menunjukkan beberapa parameter yang digunakan pada kinematika mobile robot jenis differential drive. Beberapa parameter tersebut antara lain:

a. $(x, y)$ merupakan koordinat posisi dari robot.

b. $v$ merupakan kecepatan linier dari robot.

c. $V_{L}$ dan $V_{R}$ merupakan kecepatan linier dari masing-masing roda (kanan dan kiri).

d. $\theta$ merupakan orientasi dari robot. e. $R$ merupakan jari-jari rotasi dari robot.

f. $L$ merupakan jarak dari kedua roda.

Nilai $V_{L}$ dan $V_{R}$ diperoleh dari pembacaan encoder pada setiap sumbu roda robot. Encoder yang digunakan pada penelitian ini memiliki resolusi 20 pulsa/rotasi dan dilakukan sampling setiap detik untuk mendapatkan jumlah pulsa $n$. Sehingga apabila roda memiliki diameter $d$, maka nilai $V_{L}$ dan $V_{R}$ dapat dihitung dengan menggunakan persamaan:

$$
V_{R / L}=\frac{n}{20} \times \pi d
$$

Hubungan antara masing-masing parameter pada Gambar 2 di atas adalah sebagai berikut [3]:

$$
\begin{gathered}
v=\frac{V_{R}+V_{L}}{2} \\
\omega=\frac{V_{R}-V_{L}}{L}
\end{gathered}
$$

Nilai $\omega$ merupakan kecepatan angular dari robot dan bernilai positif untuk putaran yang berlawanan dengan arah jarum jam.

$$
R=\frac{L}{2} \times \frac{V_{R}+V_{L}}{V_{R}-V_{L}}
$$

Dari persamaan (2) dapat terlihat bahwa $\omega$ akan bernilai 0 apabila nilai $V_{R}$ sama dengan nilai $V_{L}$. Keadaan tersebut akan terpenuhi ketika robot bergerak lurus, yaitu apabila kecepatan roda kanan dan kiri sama besar. Namun, hal yang sebaliknya terjadi pada persamaan (3). Nilai $R$ akan menjadi tak hingga apabila robot bergerak lurus dikarenakan nilai $V_{R}$ dan $V_{L}$ sama besar.

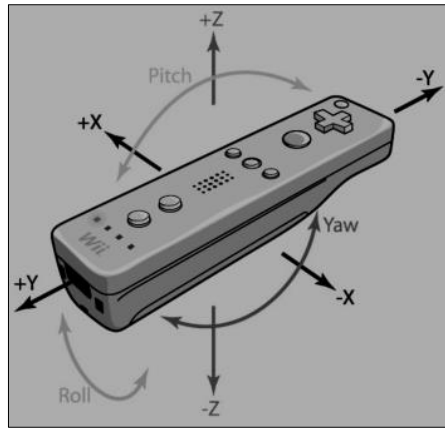

Gambar 1. Sistem Koordinat Wiimote

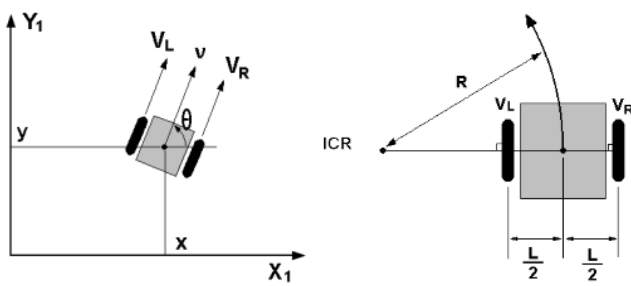

Gambar 2. Model Differential Drive 


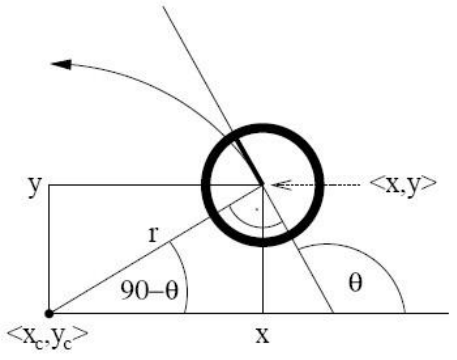

Gambar 3. Model Pergerakan Robot [4]

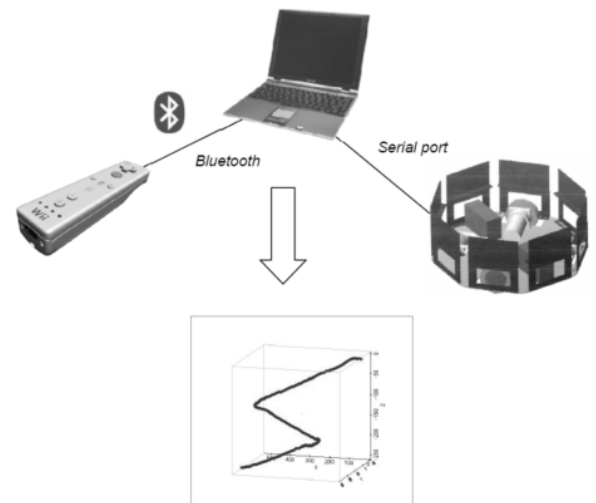

Gambar 4. Deskripsi Umum Sistem

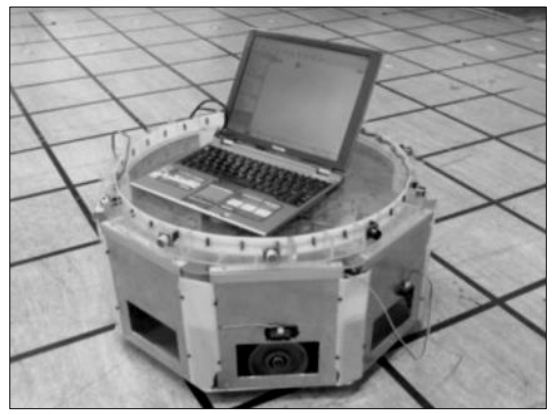

Gambar 5. Mobile Robot dan Laptop

Ketika robot bergerak lurus selama selang waktu $\Delta t$ dengan $v$ konstan, maka posisi robot selanjutnya $\left(x^{\prime}, y^{\prime}\right)$ dapat dicari dengan menggunakan persamaan berikut:

$$
\begin{aligned}
& x^{\prime}=x+v \Delta t \cos \theta \\
& y^{\prime}=y+v \Delta t \sin \theta
\end{aligned}
$$

Namun apabila robot sedang dalam keadaan berbelok ke kiri atau ke kanan, model pergerakan dari Gambar 3 dapat digunakan untuk menentukan posisi dari robot dengan syarat nilai $v$ dan $\omega$ dijaga konstan. Hal ini dapat dilakukan dengan mencari nilai $x_{c}$ dan $y_{c}$ terlebih dahulu.

$$
\begin{aligned}
& x_{c}=x-\frac{v}{\omega} \sin \theta \\
& y_{c}=y+\frac{v}{\omega} \cos \theta
\end{aligned}
$$

Nilai $x_{c}$ dan $y_{c}$ ini merupakan titik pusat rotasi robot ketika sedang berbelok ke kiri atau ke kanan. Dari titik pusat ini, dapat dicari posisi dan orientasi robot selanjutnya setelah robot bergerak selama selang waktu $\Delta t$ dengan $v$ dan $\omega$ konstan, dengan menggunakan persamaan berikut:

$$
\begin{gathered}
x^{\prime}=x_{c}+\frac{v}{\omega} \sin (\theta+\omega \Delta t) \\
y^{\prime}=y_{c}-\frac{v}{\omega} \cos (\theta+\omega \Delta t) \\
\theta^{\prime}=\theta+\omega \Delta t
\end{gathered}
$$

Sehingga posisi robot pada peta dapat digambarkan berdasarkan perhitungan-perhitungan tersebut.

\section{Perancangan dan Implementasi}

Gambar 4 menunjukkan deskripsi umum sistem yang dibangun. Sistem tersebut terdiri dari Wiimote yang tersambung melalui antarmuka Bluetooth ke laptop, sedangkan laptop tersambung ke mobile robot menggunakan antarmuka kabel konversi USB to serial. Kemudian sistem ini akan diujikan pada lingkungan berkontur dan menghasilkan output berupa plot tiga dimensi dari kontur lintasan yang dilewati robot.

\subsection{Spesifikasi Mobile Robot}

Spesifikasi perangkat keras yang dimiliki mobile robot adalah sebagai berikut [6]:

a. Lingkungan operasi mobile robot

1) Berlantai dasar yang rata dan tidak bergelombang.

2) Suhu ruangan diasumsikan $\pm 25^{\circ}$ dimana komponen elektronik bekerja normal.

b. Plant mekanik

1) Robot berbentuk segi delapan yang memiliki diameter $55 \mathrm{~cm}$, tinggi $22 \mathrm{~cm}$, dan terdiri atas tiga tingkat.

2) Bahan yang digunakan untuk chassis, body, dan pembatas tingkat dua adalah plat aluminium, sedangkan untuk pembatas tingkat tiga adalah acrylic. Gambar 5 menunjukkan bentuk fisik robot dengan laptop diletakkan di atasnya.

c. Aktuator

1) Robot bergerak menggunakan dua buah roda yang memiliki diameter $12 \mathrm{~cm}$ dan metode pengendaliannya menggunakan sistem differential steering.

2) Mekanisme roda gigi antara motor dan roda penggerak menggunakan tipe spurs gear dengan perbandingan gigi 21:75.

3) Robot juga menggunakan dua buah omnidirectional wheel untuk menjaga 
keseimbangan dan sekaligus berfungsi sebagai roller.

4) Penguat dan pengendali arah putaran motor menggunakan driver motor L298.

d. Sistem pengendali dan komunikasi

1) Robot menggunakan dua buah pengendali, yaitu mikrokontroler AVR ATMEGA32 dan sebuah laptop sebagai human-machine interface.

2) Komunikasi antara mikrokontroler dan laptop menggunakan komunikasi serial RS232 dengan antarmuka kabel konversi USB to serial.

\subsection{Implementasi Perangkat Lunak}

Perangkat lunak yang diimplementasikan terdiri dari dua bagian, yaitu:

a. Bagian pertama merupakan program utama yang dijalankan dari laptop. Program ini akan menangani rutin komunikasi dengan Wiimote melalui konektivitas Bluetooth, komunikasi dengan mikrokontroler melalui port serial, melakukan perhitungan-perhitungan posisi dan kinematika robot, serta menghasilkan keluaran berupa ilustrasi grafik.

b. Bagian kedua merupakan program yang ditanamkan ke dalam mikrokontroler ATMEGA32. Program ini bertugas untuk menerima perintah dari laptop melalui komunikasi serial, yang selanjutnya akan mengendalikan pergerakan mobile robot dengan membangkitkan sinyal PWM.

Dalam implementasinya, program utama yang dijalankan dari laptop ditulis dalam bahasa pemrograman $\mathrm{C}++$ menggunakan perangkat lunak Code::Blocks v8.02 yang bersifat open source dan cross platform. Sedangkan program yang ditanamkan ke dalam mikrokontroler ditulis dalam bahasa pemrograman $\mathrm{C}$ menggunakan perangkat lunak CodeVisionAVR v1.25.

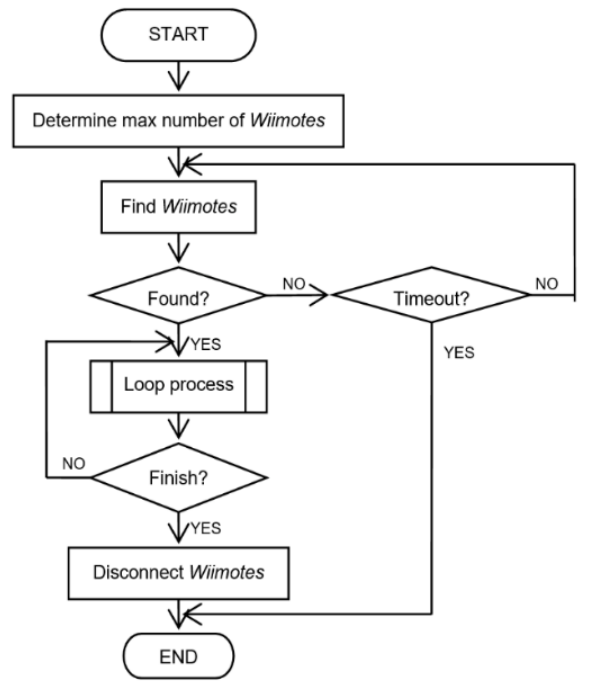

Gambar 6. Diagram Alir Komunikasi Wiimote

\subsubsection{Komunikasi Wiimote}

Wiimote berkomunikasi dengan laptop menggunakan antarmuka Bluetooth. Oleh karena itu, laptop yang akan digunakan harus memiliki perangkat Bluetooth terlebih dahulu, baik itu yang telah terintegrasi di dalam laptop atau dapat juga ditambahkan perangkat USB Bluetooth bagi laptop yang belum memilikinya. Adapun laptop yang digunakan dalam penelitian ini telah terintegrasi dengan Bluetooth dan menggunakan Toshiba Bluetooth Stack sebagai driver-nya. Gambar 6 menunjukkan diagram alir komunikasi Wiimote dengan laptop.

Sebelum dilakukan proses perhitungan posisi dan penggambaran grafik, dilakukan pengambilan data dari sensor yang terdapat pada Wiimote. Data yang diambil adalah data pitch berupa besaran sudut kemiringan dalam derajat. Nilai sudut ini bernilai positif ketika robot sedang berjalan menanjak dan bernilai negatif ketika robot sedang berjalan menurun. Secara default, fitur motion sensing pada Wiimote berada dalam keadaan tidak aktif, sehingga untuk mengecek apakah Wiimote mengalami perubahan kemiringan atau tidak, fitur tersebut perlu diaktifkan terlebih dahulu. Aktivasi fitur motion sensing ini dapat dilakukan dengan memanggil fungsi wiiuse_motion_sensing() .

wiiuse motion sensing(wiimotes [0],1);

Setelah fitur motion sensing diaktifkan, pengecekan terhadap perubahan kemiringan yang dialami oleh Wiimote dapat dilakukan dengan memeriksa event yang terjadi pada Wiimote dengan menggunakan baris perintah sebagai berikut:

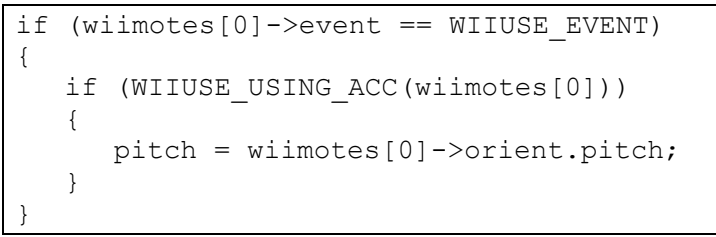

Dari baris program di atas dapat dilihat bahwa ekspresi if yang pertama akan bernilai TRUE apabila telah terjadi event pada wiimotes[0]. Jika benar, ekspresi if yang kedua akan memeriksa apakah event tersebut terjadi karena perubahan kemiringan pada Wiimote. Jika benar terjadi karena perubahan kemiringan, maka program akan menyimpan nilai sudut kemiringan Wiimote ke dalam variabel pitch. Nilai sudut pitch ini akan digunakan dalam menentukan koordinat $z$ dalam penggambaran plot tiga dimensi lintasan yang dilewati robot. Jika nilai $z$ terlebih dahulu diinisiasi dengan 0 , maka koordinat $z$ selanjutnya $(z ')$ setelah robot bergerak selama selang waktu $\Delta t$ dengan $v$ konstan dan sudut pitch $\theta$ dapat dicari dengan menggunakan persamaan berikut:

$$
z^{\prime}=z+v \Delta t \sin \theta
$$




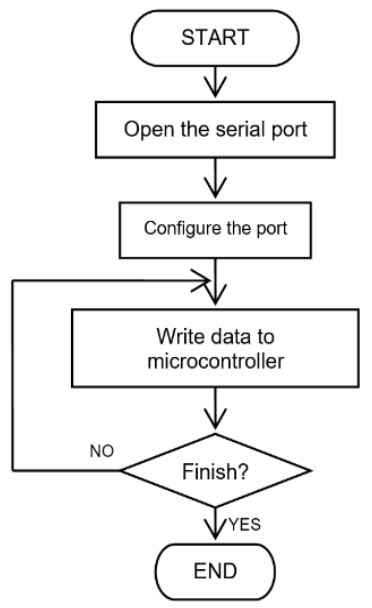

Gambar 7. Diagram Alir Komunikasi Mikrokontroler

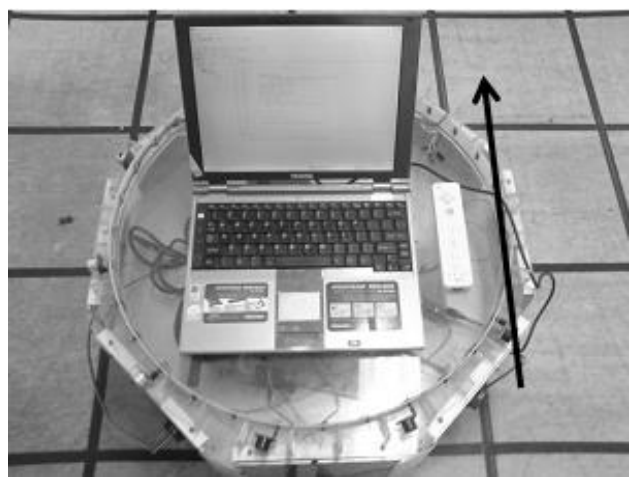

Gambar 8. Posisi Wiimote di Atas Mobile Robot

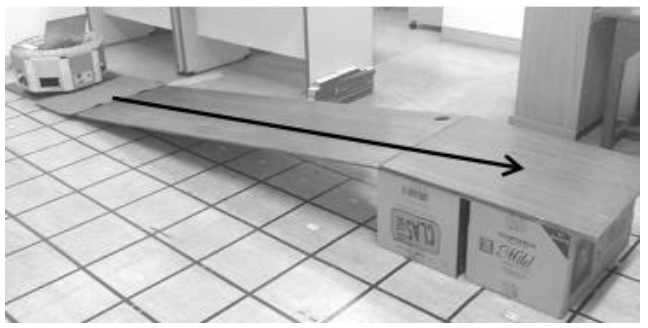

Gambar 9. Pengujian di Dalam Laboratorium

Untuk menentukan setiap koordinat $(x, y, z)$ pada penggambaran plot tiga dimensi, nilai $(x, y, z)$ awal terlebih dahulu diinisiasi dengan $(0,0,0)$. Kemudian dilakukan proses iterasi dari persamaan (1) sampai dengan (12) setiap satu detik, sehingga ketika diimplementasikan ke dalam program, nilai $\Delta t$ pada persamaan (5), (6), serta (9) sampai dengan (12) adalah 1 dan diperoleh koordinat $(x, y, z)$ baru pada setiap detiknya. Nilai-nilai koordinat ini disimpan di dalam array untuk kemudian digambarkan sebagai plot tiga dimensi dengan menggunakan library OpenCV.

\subsubsection{Komunikasi Mikrokontroler}

Mikrokontroler berkomunikasi dengan laptop melalui port serial dengan menggunakan antarmuka kabel USB to serial. Gambar 7 menunjukkan diagram alir komunikasi mikrokontroler.

Komunikasi serial ini pada aplikasinya digunakan untuk mengirimkan suatu perintah kepada mikrokontroler untuk menggerakkan mobile robot. Data yang dikirimkan terdiri atas tiga komponen, yaitu kecepatan motor kiri, kecepatan motor kanan, dan orientasi dari kedua motor. Sementara itu, mikrokontroler bertugas untuk selalu siap menerima data yang dikirimkan oleh laptop dari port serial.

\section{Pengujian}

Sebelum melakukan pengujian, ada beberapa hal yang perlu dipersiapkan. Persiapan meliputi halhal seperti menyiapkan koneksi Bluetooth antara Wiimote dengan laptop serta pengaturan tata letak Wiimote dan laptop di atas mobile robot.

Mula-mula aktifkan mode pencarian pada Wiimote telebih dahulu dengan cara menekan tombol 1 dan 2 secara bersamaan. Kemudian pada menu Bluetooth yang terdapat pada laptop, aktifkan koneksi dengan "Nintendo RVL-CNT-01" yang merupakan representasi dari Wiimote.

Kemudian letakkan laptop dan Wiimote di atas mobile robot dengan posisi Wiimote menghadap ke depan seperti ditunjukkan oleh Gambar 8. Setelah laptop dan Wiimote diposisikan dengan benar, maka langkah selanjutnya adalah menyambungkan kabel USB to serial ke port USB laptop dan mulai menjalankan program yang telah diimplementasikan.

Ketika program pertama kali dijalankan, program akan membuka port serial terlebih dahulu, diikuti dengan membuat koneksi dengan Wiimote. Apabila berhasil, maka akan tampil pesan "Connected to Wiimote" pada jendela konsol. Selanjutnya dilakukan pengujian pada beberapa tempat sebagai berikut:

\section{a. Laboratorium AVRG}

Lokasi ini merupakan lokasi pengujian pertama yang dilakukan. Di dalam laboratorium, lingkungan dapat dibuat sedemikian rupa sehingga mudah dilakukan pengukuran untuk perbandingan antara hasil yang diperoleh dengan keadaan sebenarnya. Pengujian ini hanya terdiri dari satu jalur lurus yang menanjak seperti yang ditunjukkan oleh Gambar 9.

Pada hasil pemetaan yang ditunjukkan oleh Gambar 10 terlihat sedikit noise berupa permukaan yang tidak sepenuhnya halus dan rata. Hal ini disebabkan karena mobile robot mengalami sedikit getaran pada saat menanjak, sehingga hasil pembacaan Wiimote menjadi sedikit terganggu. Kemudian pada hasil akhir sumbu $\mathrm{X}$ menunjukkan nilai 314, yang berarti robot telah maju sejauh $314 \mathrm{~cm}$ pada bidang alasnya (bukan pada bidang miring), dan kondisi sebenarnya adalah sejauh $330 \mathrm{~cm}$ atau 11 grid lantai. Sedangkan pada sumbu $Z$ menunjukkan nilai 31 , yang berarti robot lebih tinggi $31 \mathrm{~cm}$ dari posisi 
awal, dan kondisi sebenarnya adalah $29 \mathrm{~cm}$. Perbedaan yang tidak terlalu signifikan ini menunjukkan bahwa sistem telah berfungsi cukup baik dan akurat.

\section{b. Pelataran parkir}

Lokasi kedua bertempat di pelataran parkir depan gedung Ahmad Bakrie (dulu disebut Labtek VIII). Pengujian ini melibatkan satu belokan ke kiri dan permukaannya menurun seperti yang ditunjukkan oleh Gambar 11, sedangkan hasil pemetaan di lokasi ini dapat dilihat pada Gambar 12.

\section{c. Selasar koridor}

Lokasi ketiga bertempat di selasar koridor menuju ke pelataran parkir depan gedung Ahmad Bakrie (dulu disebut Labtek VIII). Pengujian ini terdiri dari satu belokan ke kiri ditambah satu belokan ke kanan dan permukaannya menurun seperti yang ditunjukkan oleh Gambar 13, sedangkan hasil pemetaan di lokasi ini dapat dilihat pada Gambar 14.

\section{d. Ramp Campus Center}

Lokasi keempat bertempat di ramp Campus Center. Gambar 15 menunjukkan hasil pemetaan di lokasi ini, sedangkan Gambar 16 menunjukkan keadaan lokasi yang terdiri dari beberapa belokan dan permukaannya menurun.

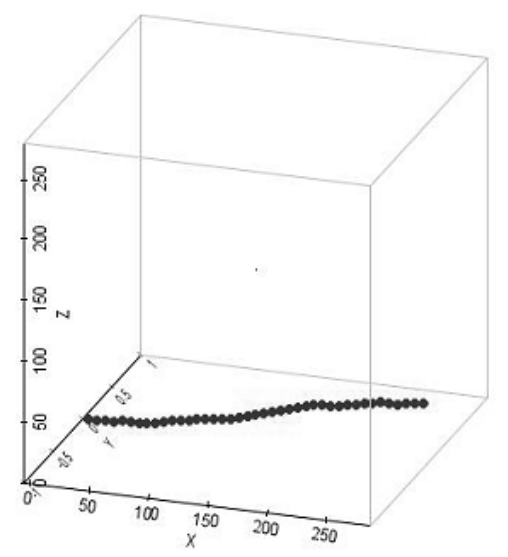

Gambar 10. Hasil Pemetaan di Dalam Laboratorium

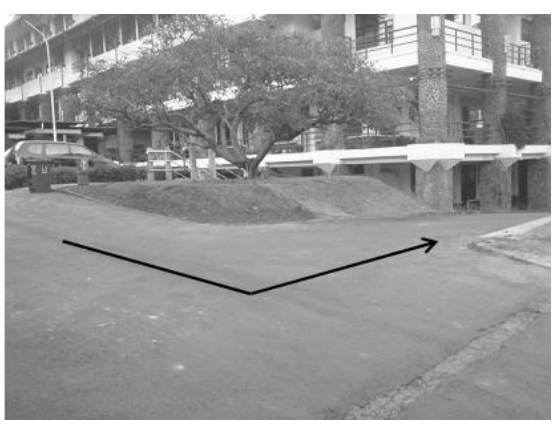

Gambar 11. Pelataran Parkir

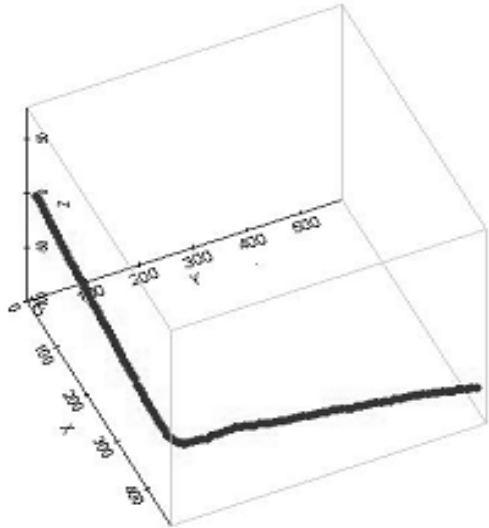

(a)

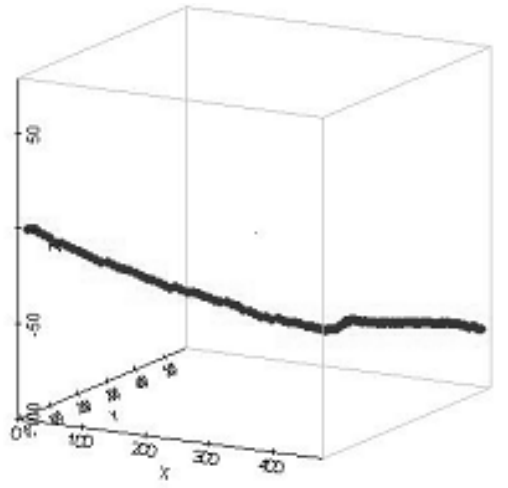

(b)

Gambar 12. Hasil Pemetaan di Pelataran Parkir

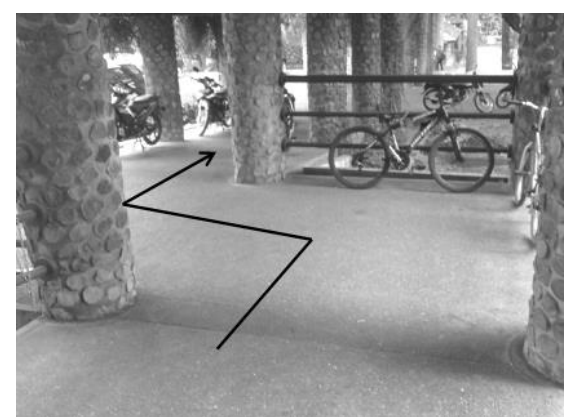

Gambar 13. Selasar Koridor

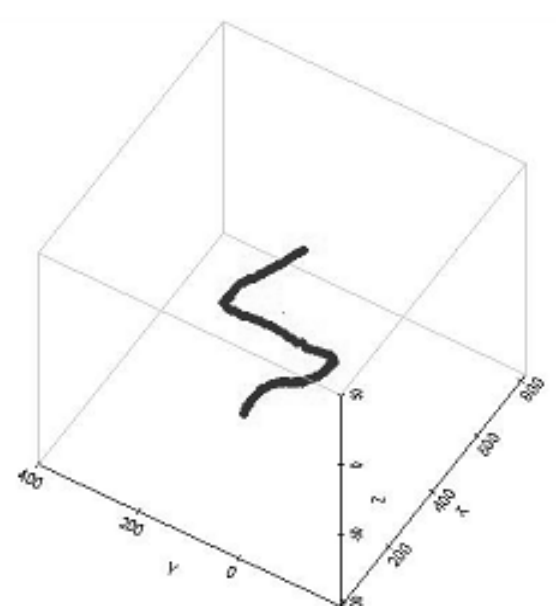

(a) 


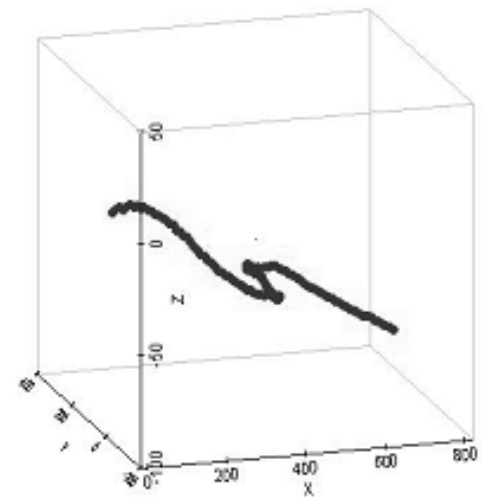

(b)

\section{Gambar 14. Hasil Pemetaan di Selasar Koridor}

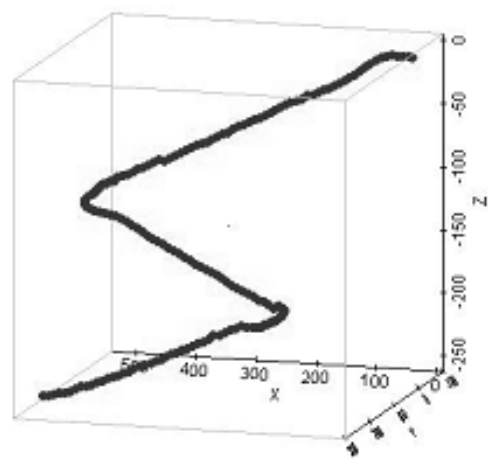

(a)

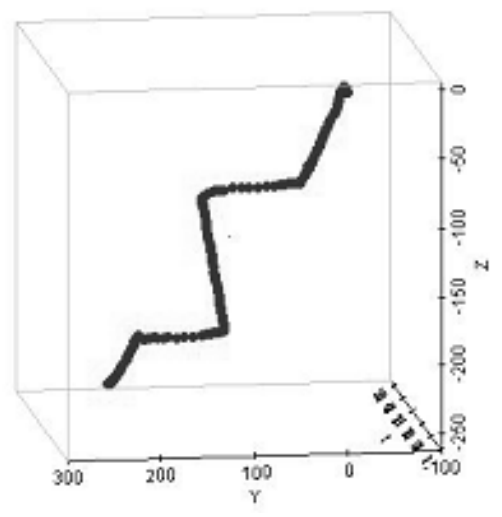

(b)

\section{Gambar 15. Hasil Pemetaan di Ramp Campus Center}

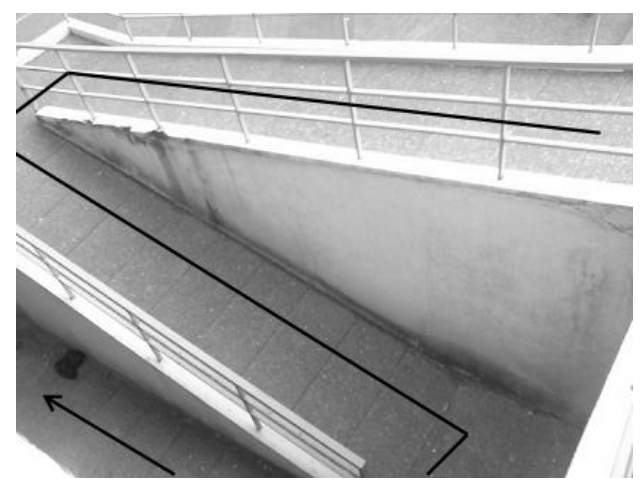

Gambar 16. Ramp Campus Center
Tabel 1. Pemetaan Jarak pada Sumbu X, Y, dan Z

\begin{tabular}{|c|c|c|c|c|c|c|}
\hline \multirow{2}{*}{ Lokasi } & \multicolumn{3}{|c|}{ Hasil Pemetaan $(\mathbf{c m})$} & \multicolumn{3}{c|}{ Jarak sebenarnya (cm) } \\
\cline { 2 - 7 } & $\Delta \mathbf{X}$ & $\Delta \mathbf{Y}$ & $\Delta \mathbf{Z}$ & $\Delta \mathbf{X}$ & $\Delta \mathbf{Y}$ & $\Delta \mathbf{Z}$ \\
\hline 1 & 314 & - & 31 & 330 & - & 29 \\
\hline 2 & 476 & 570 & 65 & 500 & 600 & 60 \\
\hline 3 & 837 & 210 & 80 & 900 & 200 & 75 \\
\hline 4 & 514 & 215 & 260 & 550 & 200 & 250 \\
\hline
\end{tabular}

Tabel 2. Perhitungan Selisih dan Error

\begin{tabular}{|c|c|c|c|c|c|c|}
\hline \multirow{2}{*}{ Lokasi } & \multicolumn{3}{|c|}{ Selisih (cm) } & \multicolumn{3}{c|}{ Error } \\
\cline { 2 - 7 } & $\Delta \mathbf{X}$ & $\Delta \mathbf{Y}$ & $\Delta \mathbf{Z}$ & $\Delta \mathbf{X}$ & $\Delta \mathbf{Y}$ & $\Delta \mathbf{Z}$ \\
\hline 1 & 16 & - & 2 & $4,8 \%$ & - & $6,9 \%$ \\
\hline 2 & 24 & 42 & 4 & $4,8 \%$ & $7 \%$ & $6,7 \%$ \\
\hline 3 & 63 & 10 & 5 & $7 \%$ & $5 \%$ & $6,7 \%$ \\
\hline 4 & 36 & 13 & 18 & $6,5 \%$ & $6,5 \%$ & $7,2 \%$ \\
\hline
\end{tabular}

Perbandingan hasil pemetaan dan keadaan sebenarnya dari keempat lokasi tersebut ditunjukkan pada Tabel 1, sedangkan perhitungan selisih dan error ditunjukkan pada Tabel 2. Dari tabel tersebut dapat disimpulkan bahwa error berkisar antara $4,8 \%$ sampai 7,2\% dengan rata-rata error adalah 6,3\%. Sehingga rata-rata akurasi yang diperoleh adalah $100 \%-6,3 \%=93,7 \%$.

\section{Kesimpulan}

Sistem yang dibangun dapat melakukan tugas dan fungsinya dengan baik, yaitu membuat peta kontur lingkungan yang mendekati keadaan yang sebenarnya dengan akurasi rata-rata sebesar 93\%. Beberapa noise yang terdapat pada peta disebabkan oleh permukaan tanah yang sedikit bergelombang. Hal itu dapat mengganggu pembacaan informasi dari Wiimote karena accelerometer yang digunakan memiliki tingkat sensitivitas yang cukup tinggi.

Sistem yang dibangun dapat digunakan dan dikombinasikan dengan metoda pemetaan lain untuk membentuk interpretasi terhadap lingkungan yang lebih lengkap pada penelitian yang lebih lanjut.

\section{Daftar Pustaka}

[1] Analog Devices, "ADXL330 Accelerometer Datasheet", Diakses pada Februari 2015 http://www.analog.com/static/importedfiles/data_sheets/ADXL330.pdf

[2] Borenstein, J., B. Everett, dan L. Feng, "Navigating Mobile Robots: Systems and Techniques", Massachusetts, A. K. Peters, Ltd., 1996.

[3] Dudek, Gregory, dan Michael Jenkin, "Computational Principles of Mobile Robotics", United Kingdom, Cambridge University Press, 2010.

[4] Thrun, Sebastian, Wolfram Burgard, dan Dieter Fox, "Probabilistic Robotics", Seattle, University of Washington, 2000.

[5] Thrun, Sebastian, "Robotic Mapping: A Survey", Pittsburgh, Carnegie Mellon University, 2002. 
[6] Wardhana, Aryo, "Perancangan dan Realisasi Platform serta Sistem Penggerak Autonomous Mobile Robot", Bandung, Institut Teknologi Nasional, 2007.

[7] Zunt, Dominik, "Who Did Actually Invent The Word "Robot" and What Does It Mean?", Karel Čapek website, diakses pada 13 Januari 2015. 